Systematic Review

Revisão Sistemática

Ana Lívia Libardi Bertachini ${ }^{1}$ Altair Cadrobbi Pupo ${ }^{2}$

Marina Morettin ${ }^{3}$

Maria Angelina Nardi Martinez ${ }^{4}$ Maria Cecília Bevilacqua (in memorian) ${ }^{5}$ Adriane Lima Mortari Moret ${ }^{6}$

Sheila Andreoli Balen ${ }^{7}$ Regina Tangerino de Souza Jacob ${ }^{6}$

Keywords

Hearing Loss

Hearing Aids

Cochlear Implantation Self-Help Devices

Noise

Child

Faculty

Learning

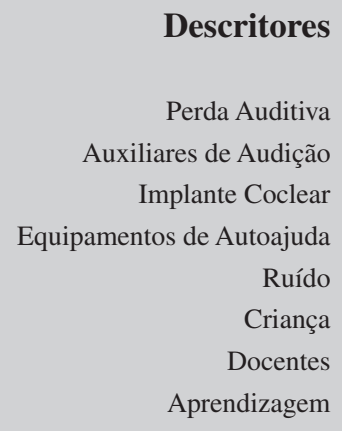

Correspondence address:

Regina Tangerino de Souza Jacob

Departamento de Fonoaudiologia, Faculdade de Odontologia de Bauru, Universidade de São Paulo

Alameda Doutor Octávio Pinheiro Brisolla, 9-75, Bauru (SP), Brasil, CEP: 17012-901.

E-mail: reginatangerino@usp.br

Received on: 06/02/2014

Accepted on: 10/29/2014

\section{Frequency Modulation System and speech perception in the classroom: a systematic literature review}

\section{Sistema de Frequência Modulada e percepção da fala em sala de aula: revisão sistemática da literatura}

\begin{abstract}
Purpose: This review aimed at presenting the benefits regarding the speech perception in noise shown by children who wear hearing aid devices and/or cochlear implants with the Frequency Modulation (FM) System at school. Research strategy: A bibliographic survey was conducted in an electronic database with standardized search until the year 2012, and a manual search was performed by using specific keywords. Selection criteria: For the selection and evaluation of the scientific studies chosen in the search, criteria were established covering the following aspects: type of study, participants, adopted intervention, and evaluation of results. Data analysis: The FM system was verified to improve speech perception and speech threshold in noise in all studies. Results: Regarding the performance as to type, the best results were obtained when children used the personal FM system, followed by the table and the sound field systems. Conclusion: After extensive review of national and international literature, it was concluded that the studies indicate the need for further research concerning mainly the impact of the FM system on the school performance of children who have sensory devices coupled to the FM system. Findings in the literature with relation to the publications focused on speech perception in noise did not relate educational and auditory aspects.
\end{abstract}

\section{RESUMO}

Objetivo: Esta revisão teve como objetivo apresentar os benefícios, em relação à percepção de fala no ruído, que crianças usuárias de aparelho de amplificação sonora individual e/ou implante coclear demonstram com o Sistema de Frequência Modulada (FM) na escola. Estratégia de pesquisa: Foi realizado levantamento bibliográfico conduzido em base eletrônica de dados com busca padronizada até o ano de 2012 e busca manual, utilizando palavras-chave específicas. Critérios de seleção: Para a seleção e avaliação dos estudos científicos levantados na busca, foram estabelecidos critérios contemplando os aspectos: tipo de estudo, participantes, intervenção adotada e avaliação dos resultados. Análise dos dados: Foi possível verificar que o Sistema de FM melhora a percepção de fala e o limiar de fala no ruído, sendo esses resultados encontrados em todos os estudos. Resultados: Em relação ao desempenho quanto ao tipo, os melhores resultados foram obtidos quando as crianças utilizavam o Sistema de FM pessoal, seguido pelo de mesa e o campo livre. Conclusão: Após a extensa revisão da literatura nacional e internacional, foi possível concluir que os estudos indicam a necessidade de pesquisas voltadas principalmente ao impacto do Sistema de FM no desempenho escolar de crianças usuárias de dispositivos sensoriais acoplados ao Sistema de FM. O que foi encontrado na literatura específica quanto às publicações voltadas à questão da percepção de fala no ruído não relacionaram os aspectos educacionais e auditivos.

Study carried out at the Speech Language and Audiology Department, Dental School of Bauru, Universidade de São Paulo - USP - Bauru (SP), Brazil.

(1) Graduate Program in Speech Language Pathology and Audiology, Dental School of Bauru, Universidade de São Paulo - USP - Bauru (SP), Brazil.

(2) Speech Language Pathology and Audiology Course, Pontifícia Universidade Católica de São Paulo - PUCSP - São Paulo (SP), Brazil.

(3) Speech Language Pathology and Audiology Department, Dental School of Bauru, Universidade de São Paulo - USP - Bauru (SP), Brazil.

(4) Pontifícia Universidade Católica de São Paulo - PUC-SP - São Paulo (SP), Brazil.

(5) Speech Language Pathology and Audiology Department, Dental School of Bauru, Universidade de São Paulo - USP - Bauru (SP); Center of Audiological Research, Hospital for the Rehabilitation of Craniofacial Anomalies, at Universidade de São Paulo - USP - Bauru (SP), Brazil.

(6) Speech Language Pathology and Audiology Department, Dental School of Bauru, Universidade de São Paulo - USP - Bauru (SP), Brazil.

(7) Speech Language Pathology and Audiology Department, Universidade Federal do Rio Grande do Norte UFRN - Natal (RN), Brazil.

Conflict of interests: nothing to declare. 


\section{INTRODUCTION}

Recent progress in the treatment of children with hearing impairment has enabled the access to the auditory perception of speech sounds for individuals with sensorineural hearing loss, thus providing valuable benefits for communication and quality of life of these people.

Such progress can mostly be seen in sensory devices applied to hearing impairment. Among them, hearing aid devices and cochlear implant (CI) stand out, as well as the Frequency Modulation (FM) systems.

With early diagnosis and the activation of the National Policy of Hearing Health Care ${ }^{(1)}$, implemented in September 2004, many children with hearing impairment gained free access to sensory devices such as the hearing aids and the CI; so, they could go to school and use these devices, which favors the learning process in the school context ${ }^{(2)}$. Currently, we are living in a new historical moment, with the implementation of the program "Viver sem Limites"(3), which is organized in four principles: access to education, social inclusion, health care, and accessibility of people with disabilities in a vulnerable situation, as well as to promote initiatives with the Union, state, and city. According to the National Policy on Special Education ${ }^{(4)}$, the integration between education and school refers to the process of educating — teaching the child both with and without impairment, in the same group, part or full time at school.

When the child has a disability, it is important to ensure access to education. The FM system is seen as an alternative among all support resources used by students with hearing impairment, aiming at assisting the integration between education and school. For some authors, the FM system is the most important and essential educational tool that has ever been developed for people with hearing impairment; regardless of type (personal, self-contained, and free-field), it is the most effective means that favors signal-to-noise ratio, especially in an education environment ${ }^{(5-7)}$.

The benefit regarding speech perception in the school environment of children with hearing impairment wearing sensory devices (hearing aid and CI) together with the FM system is important in school and in studies of the Audiology field.

The current hearing health reality in public services provides better conditions for the development of the auditory function and language among children who received an early diagnosis of hearing impairment; therefore, they have more access to specialized treatment. However, even if these children show good functional performance in terms of hearing and oral language, during their development and when attending school they are faced with many obstacles, such as noise in the classroom, distance between the teacher and the child (speaker-listener), and reverberation in the classroom. These adverse conditions are mostly owed to the large number of students in the same classroom and classrooms with little or no acoustic treatment; besides, teachers in general have little or no prior knowledge regarding hearing impairment. It is estimated that guidance on management and necessary conditions to value the use of sensory devices is also scarce.
These adverse conditions lead to difficulties acquiring academic content, and, in more severe cases, the educational performance is totally harmed.

In this sense, the FM system is an electronic device used for the accessibility of people with hearing impairment, especially in the educational setting. It enables children with hearing impairment who wear sensory devices to perceive the voice of the teacher in the classroom, regardless of distance and noise that is usually generated in classrooms. Therefore, it is considered to be an assistive instrument that is part of the treatment for hearing impairment. This resource is used in school, regardless of age; however, it is potentially addressed to children.

In Brazil, sensory devices (hearing aid and CI) are already made available by the Unified Health System (SUS), and the use of the FM system was an important step toward the academic accessibility of children with hearing impairment since it was included in Recommendation n. 1,274, from June 25, 2013, in the table of Procedures, Medications, Orthoses, Prostheses and Special Materials of SUS ${ }^{(8)}$.

\section{OBJECTIVE}

As the essential principle of a study based on evidence, the question of this study's investigation was: does the child with hearing impairment who wears sensory devices (hearing aid and CI) have benefits regarding speech perception in school environment when using the FM system in the classroom?

\section{RESEARCH STRATEGY}

The search strategy used in the literature review was oriented by the combination of nine descriptors indexed in the Health Sciences Descriptors (DeCS), in Portuguese and in English; besides, keywords that are not considered to be health sciences descriptors were also used, however, they were used to help the bibliographic survey in the databases. All of the descriptors were used in groups with, at least, two keywords (Chart 1).

The scientific databases chosen for the study were the following: LILACS, MEDLINE, SciELO, Cochrane Library, PubMed, EMBASE, Institute for Scientific Information (ISI), and Science Direct. The manual search was also conducted, with the objective of finding bibliographic references when they were not present in the electronic bases.

\section{SELECTION CRITERIA}

This study considered publications produced from 2000 to 2012 , and the last search was made in the electronic databases in October 2012.

The selection of articles followed the inclusion criteria based on the agreement of the limits of the topics and the objectives of this study. The adopted criteria were as follows:

- participants: children wearing sensory devices (hearing aids and/or CI) who attended elementary school and high school; 
stage). Afterwards, in the stage of text selection, abstracts were analyzed regarding the information available about the use of any assessment instrument on the speech perception of children enrolled in the elementary school and high school with the FM system. The full texts were analyzed when the title or the abstract left doubts (second stage). The main data from each selected paper were collected in detail in a standard file used for this study. Articles were fully read (third stage).

The descriptive analysis of the selected publications was performed according to the objectives of the review.

\section{RESULTS}

In total, 2,241 papers were identified in all of the electronic databases and in manual searches (Table 2). When these texts were preselected, based on the titles and the abstracts of all of the studies located in the electronic search, 2,233 were excluded; therefore, eight papers were fully read (Table 3 ).

In Figure 1, it is possible to see a summary of the survey conducted in the electronic databases and in the manual search.

Finally, eight papers met the inclusion criteria. From the articles included in the review, seven studies were classified as being cross-sectional, 2B level of evidence, and one was characterized as a systematic review, classified as level 2A, according to the Oxford Centre for Evidence-Based Medicine classification $^{(9)}$ (Table 1).

The systematic review was described in Chart 2 as to the name of authors, title, name of the journal, year of publication, objective of the study, study method and participants, levels of scientific evidence in each study, results, and conclusion.

Table 2. Number of articles identified in the databases and in the manual search

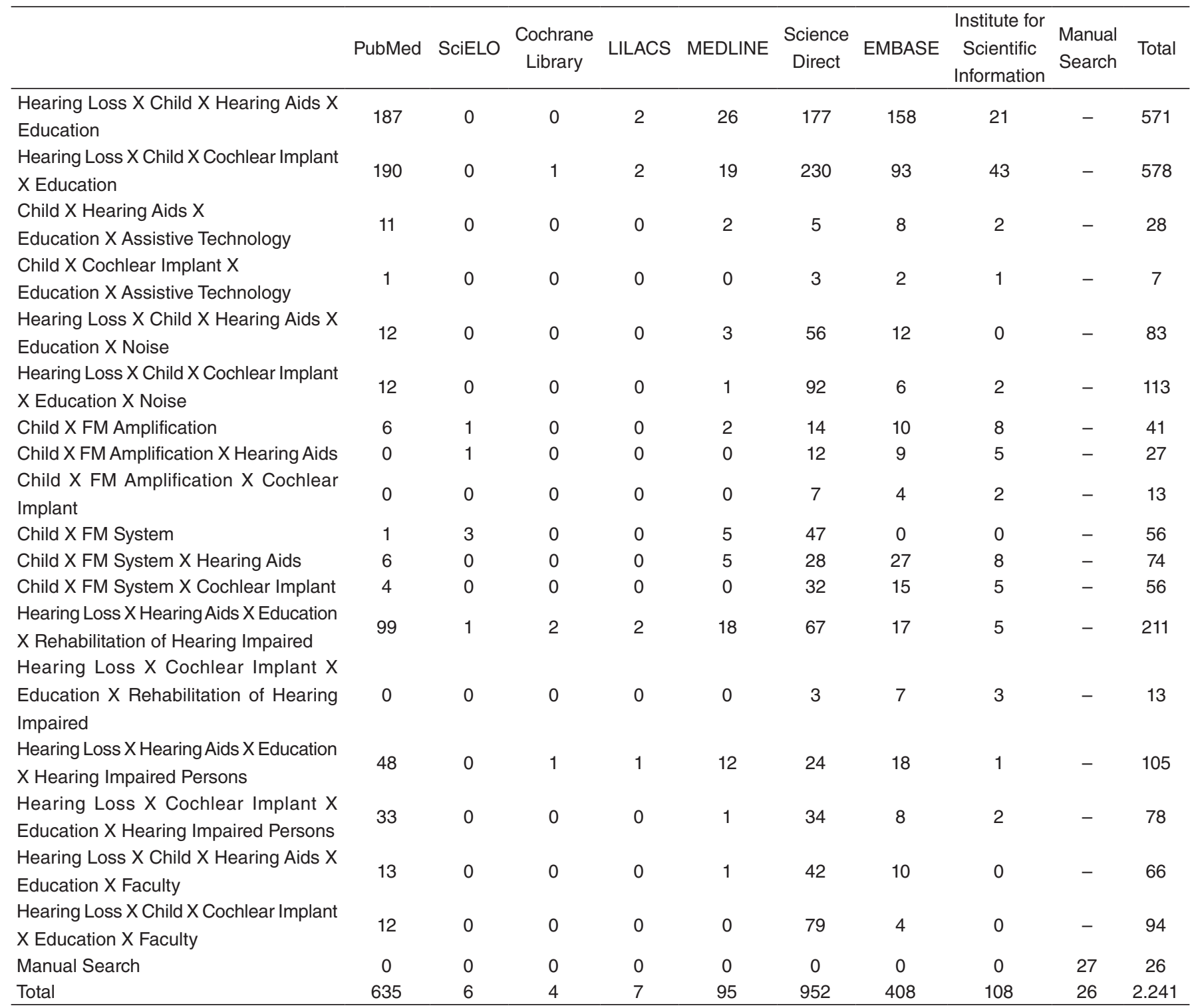


Table 3. Reasons to exclude the papers found in each analyzed database and number of papers selected for reading

\begin{tabular}{|c|c|c|c|c|c|c|c|c|c|c|}
\hline & $\begin{array}{l}\text { PubMed } \\
(\mathrm{n}=635)\end{array}$ & $\begin{array}{l}\text { Science } \\
\text { Direct } \\
(n=952)\end{array}$ & $\begin{array}{l}\text { LILACS } \\
(n=7)\end{array}$ & $\begin{array}{c}\text { MEDLINE } \\
(\mathrm{n}=95)\end{array}$ & $\begin{array}{c}\text { SciELO } \\
(n=6)\end{array}$ & $\begin{array}{l}\text { Cochrane } \\
\text { Library } \\
(n=4)\end{array}$ & $\begin{array}{c}\text { EMBASE } \\
(n=408)\end{array}$ & $\begin{array}{l}\text { Institute for } \\
\text { Scientific } \\
\text { Information } \\
(n=108)\end{array}$ & $\begin{array}{l}\text { Manual } \\
\text { search } \\
(n=26)\end{array}$ & Total \\
\hline Theme & 457 & 310 & 6 & 51 & 5 & 4 & 146 & 65 & 9 & 1.053 \\
\hline Language & 0 & 0 & 0 & 6 & 0 & 0 & 12 & 5 & 0 & 23 \\
\hline Incomplete abstracts & 58 & 407 & 0 & 0 & 0 & 0 & 32 & 0 & 0 & 497 \\
\hline Age & 12 & 3 & 0 & 0 & 0 & 0 & 0 & 0 & 2 & 17 \\
\hline Case study & 4 & 5 & 0 & 2 & 0 & 0 & 0 & 0 & 1 & 12 \\
\hline Recommendation & 0 & 0 & 0 & 0 & 0 & 0 & 0 & 0 & 1 & 1 \\
\hline
\end{tabular}

Identified studies $(n=2,241)$

Studies excluded in the preselection based on the identified titles and abstracts $(n=2,233)$

Studies included in the systematic review - reading and analysis of the texts $(n=8)$

Figure 1. Exclusion criteria of the identified studies 
Chart 2. Summary file of the studies included in the systematic review

\begin{tabular}{|c|c|c|c|c|c|c|}
\hline $\begin{array}{l}\text { Author/title/ } \\
\text { journal/year }\end{array}$ & $\begin{array}{c}\text { Study } \\
\text { location }\end{array}$ & Objective & Methods/participants & $\begin{array}{l}\text { Levels of } \\
\text { evidence }\end{array}$ & Results & Conclusion \\
\hline $\begin{array}{l}\text { Davies et al. }{ }^{(10)} \text {. } \\
\text { Speech-in-noise } \\
\text { perception of } \\
\text { children using } \\
\text { cochlear implants } \\
\text { and FM Systems. } \\
\text { The Australian } \\
\text { and New } \\
\text { Zealand J Audiol. } \\
\text { 2001;23(1):52-62. }\end{array}$ & $\begin{array}{l}\text { New } \\
\text { Zealand/ } \\
\text { Australia }\end{array}$ & $\begin{array}{l}\text { To investigate speech } \\
\text { perception in noise among } \\
\text { children wearing } \mathrm{Cl} \text { and FM }\end{array}$ & $\begin{array}{l}\text { Cross-sectional study; } \\
\text { Fourteen children aged } \\
\text { between } 7 \text { and } 17 \text { years } \\
\text { wearing } \mathrm{Cl} \text { and } \mathrm{FM}\end{array}$ & $2 B$ & $\begin{array}{l}\text { Significant benefit has been observed with } \\
\text { FM for the conditions of S/N } 0 \text { and } 3 \mathrm{~dB} \text {. } \\
\text { There was interaction between the age } \\
\text { of the child and the benefit of FM: older } \\
\text { children benefitted more from it. Younger } \\
\text { children had varied results. A small } 3 \mathrm{~dB} \\
\text { increase in the level of noise had a negative } \\
\text { effect on speech perception, and the use } \\
\text { of an FM system helped to control these } \\
\text { effects for most children }\end{array}$ & $\begin{array}{l}\text { The use of FM provided } \\
\text { significant improvement } \\
\text { for children in terms of } \\
\text { speech perception in } \\
\text { noise }\end{array}$ \\
\hline
\end{tabular}

Davies et al. ${ }^{(10)}$

Speech-in-noise

perception of

children using

cochlear implants Zealand/ perception in noise among

The Australian

2001;23(1):52-62
Ideal acoustic room: the speech perception
To investigate if free-field FM

in the classroom improves Cross-sectional study speech perception;

Iglehart ${ }^{(11)}$.

Speech perception by students with using soundfield systems in classrooms. Am J Audiol. 2004;13:62-72. cochlear implants
To verify the effectiveness of and 4 girls); the FM system in free field Severe to deep bilateral loss: when compared to the desktop They wear the $\mathrm{Cl}$, however, FM system, analyzing the they do not wear the performance in acoustically hearing aid device in the poor and ideal classrooms; contralateral ear; To verify if the FM system in Age of the participants: 6 free field minimizes noise and years and 4 months to 16 reverberation in an acoustically years and 1 month poor classroom results with each model were: $40 \%$ hits without the FM system in free field; $50 \%$ hits with the FM system in free field close to the wall, and $45 \%$ hits with the desktop FM;

The two amplification systems were

beneficial to the speech perception of children wearing $\mathrm{Cl}$ regarding the nonuse of these devices both FM system in free field, $23 \%$ hits with the FM system in free field close to the wall, and $38 \%$ hits with the desktop FM system; Both types of the FM system provided significant benefit for students with $\mathrm{Cl}$ in relation to the nonuse of the device. This benefit was obtained in the two analyzed environments (acoustically poor and ideal); There was no significant difference in speech perception when using the desktop FM system and the free-field system close to the wall when in the ideal room. In the acoustically poor room, the desktop FM system presented more benefits in an ideal and in a poor environment. In an ideal room, both systems were similar, and only for the poor environment, the desktop FM system was the most effective one in terms of speech perception due to the proximity of the microphone and the $\mathrm{Cl}$

\begin{tabular}{|c|c|c|}
\hline $\begin{array}{l}\text { Anderson and } \\
\text { Goldstein }^{(12)} \text {. } \\
\text { Speech perception } \\
\text { benefits of FM and } \\
\text { infrared devices } \\
\text { to children with } \\
\text { hearing aids in a } \\
\text { typical classroom. } \\
\text { Lang Speech } \\
\text { Hear Serv Sch. } \\
2004 ; 35: 169-84 .\end{array}$ & $\begin{array}{l}\text { United } \\
\text { States }\end{array}$ & $\begin{array}{l}\text { To investigate speech } \\
\text { perception among children } \\
\text { wearing hearing aid devices } \\
\text { exposed to noise and } \\
\text { reverberation in the classroom; } \\
\text { To investigate the three types } \\
\text { of amplification technology } \\
\text { (free-field system by infrared, } \\
\text { desktop FM system, personal } \\
\text { FM system) among the same } \\
\text { children; } \\
\text { To investigate the participants } \\
\text { and relatives regarding their } \\
\text { favorite technology }\end{array}$ \\
\hline
\end{tabular}
and relatives regarding their
Cross-sectional study; Eight children wearing hearing aid devices; Age of the participants: between 9 and 12 years
2B
Participants presented better speech recognition with the three types of amplification system. In a room with noise and reverberation, eight participants aged between 9 and 12 years did not present differences in the results of the free-field FM system by infrared and without hearing aid devices. The benefit of speech perception was clear when the desktop FM system and the personal FM system were used. Participants preferred to use the desktop FM system and the personal FM system in a room with reverberation and noise
According to the authors, children with hearing impairment need to wear the FM system in the classroom, which allows the access to verbal instruction

Anderson et al. ${ }^{(13)}$.
Benefit of $\mathrm{S} / \mathrm{N}$
enhancing
devices to speech
perception of
children listening in United
a typical classroom States
with hearing aids or
a cochlear implant.
J Educ Audiol.
2005;12:16-30.

To investigate the speech perception skills of children wearing hearing aid devices and/or $\mathrm{Cl}$ when exposed in classroom with noise and reverberation; To investigate the $\mathrm{S} / \mathrm{N}$ ratio with mild to severe loss; the three types of infrared wall Three experimental groups: technology; desktop FM system (1) 8 children wearing and personal FM system among children wearing hearing aid devices or $\mathrm{Cl}$; To investigate which is the preference between the three amplification systems;

To relate the three previous objectives to different levels of hearing loss (mild to severe) To relate the results obtained in the acoustically ideal and nonideal classroom

hearing aid devices: 9-12

years old; (2) 9 children

8-14 years old; (3) 11

children: 8 years and 11 months old to 12 years and

11 months old. Of these 11

children, 6 had $\mathrm{Cl}$
Group 1:

Only hearing aid: $82.4 \%$ hits; Infrared: $83.1 \%$ hits;

Desktop FM system: $93.5 \%$ hits;

Personal FM system: $94.4 \%$ hits.

Group 2:

Only hearing aid: $87.3 \%$ hits;

Infrared: $88 \%$ hits;

Desktop FM system: $92.4 \%$ hits;

Personal FM system: $92.6 \%$ hits.

Group 3:

Only hearing aid: $77.0 \%$ hits;

Infrared: $70 \%$ hits;

wearing hearing aid devices:

Desktop FM system: $87.6 \%$ hits

Personal FM system: $91.8 \%$ hits.

Word recognition:

differences were found with device is required

the infrared compared to the use of hearing (personal FM system). aid devices and $\mathrm{Cl}$ alone;

2) There was no difference between the benefits coming from desktop and the personal FM system;

From the 28, 11 had higher score of speech perception with the free-field FM system

when compared to the isolated use of

hearing aid devices or $\mathrm{Cl}$.

The personal FM system had the highest

score among the 28 participants
In a normally noisy and reverberating classroom, the isolated use of sensory devices (AASI or IC) is not (1) 
Chart 2. Continuation

\begin{tabular}{|c|c|c|c|c|c|c|}
\hline $\begin{array}{l}\text { Author/title/ } \\
\text { journal/year }\end{array}$ & $\begin{array}{c}\text { Study } \\
\text { location }\end{array}$ & Objective & Methods/participants & $\begin{array}{l}\text { Levels of } \\
\text { evidence }\end{array}$ & Results & Conclusion \\
\hline $\begin{array}{l}\text { Schafer and } \\
\text { Thibodeau. }{ }^{(14)} \text {. } \\
\text { Speech recognition } \\
\text { in noise in children } \\
\text { with cochlear } \\
\text { implants while } \\
\text { listening in } \\
\text { bilateral, bimodal, } \\
\text { and FM- System } \\
\text { arrangements. } \\
\text { Am J Audiol. } \\
2006 ; 15: 114-26 .\end{array}$ & $\begin{array}{l}\text { United } \\
\text { States }\end{array}$ & $\begin{array}{l}\text { To assess the improvement } \\
\text { in speech perception in } \\
\text { noise provided by the three } \\
\text { types of stimulation: bilateral, } \\
\text { bimodal, and monaural with } \\
\text { the FM system }\end{array}$ & $\begin{array}{l}\text { Cross-sectional study; } \\
\text { Twenty-two children were } \\
\text { assessed: } 12 \text { of them wore } \\
\text { sequentially implanted } \\
\text { bilateral } \mathrm{Cl} \text { ( } 3 \text { male and } \\
9 \text { female participants) } \\
\text { and } 10 \text { wore unilateral } \\
\mathrm{CI} \text { with adaptation of the } \\
\text { contralateral hearing aid } \\
\text { device ( } 2 \text { male and } 8 \text { female } \\
\text { participants). } \\
\text { Age of the participants: } 3-12 \\
\text { years old. } \\
\text { All of the children wore the } \\
\text { Cl before the age of } 5 \text { and } \\
\text { use the oral language to } \\
\text { communicate }\end{array}$ & $2 B$ & $\begin{array}{l}\text { Three of the } 22 \text { children were able to } \\
\text { complete the six testing conditions; } \\
\text { The average of speech and noise thresholds } \\
\text { without FM was } 0 \text { in the } \mathrm{S} / \mathrm{N} \text { ratio, while with } \\
\text { the FM system thresholds of up to }-15 \text { were } \\
\text { reached; the lowest values were up to }-5 \text { for } \\
\text { the following condition: } \mathrm{Cl}+\text { hearing aid or } \\
\mathrm{CI} \text { with FM, } \\
\mathrm{IC}+\text { hearing aid or } \mathrm{CI} \text { with } \mathrm{FM} \text {, in which } \\
\text { results were better; } \\
\text { The average score was similar for both } \\
\text { conditions and groups, only with } \mathrm{Cl} \text { and } \mathrm{Cl}+ \\
\text { hearing aid device or } \mathrm{Cl} \text {; } \\
\text { There was no difference in the thresholds } \\
\text { of the S/N ratio for monaural and binaural } \\
\text { stimulation, nor regarding bilateral and } \\
\text { bimodal stimulation; } \\
\text { Speech perception in } \mathrm{FM} \text { conditions was } \\
\text { much better than the same conditions } \\
\text { without the FM system in more than } 20 \mathrm{~dB} \text {. }\end{array}$ & $\begin{array}{l}\text { The FM system enables } \\
\text { improvements in the } \\
\mathrm{S} / \mathrm{N} \text { ratios of up to } \\
20 \mathrm{~dB} \text {; } \\
\text { Statistically significant } \\
\text { differences were } \\
\text { detected between the } \\
\text { conditions with an FM } \\
\text { system, and better } \\
\text { when worn in both } \\
\text { sides or in the first } \\
\text { implanted side }\end{array}$ \\
\hline
\end{tabular}

\begin{tabular}{|c|c|c|c|}
\hline \multirow{10}{*}{$\begin{array}{l}\text { Schafer and } \\
\text { Kleineck }^{(15)} \text {. } \\
\text { Improvements in } \\
\text { speech recognition } \\
\text { using cochlear } \\
\text { implants and } \\
\text { three types of FM } \\
\text { Systems: a meta- } \\
\text { analytic approach. } \\
\text { J Educ Audiol. } \\
\text { 2009;15:4-14. * }\end{array}$} & & \multirow{10}{*}{$\begin{array}{l}\text { To compare speech } \\
\text { recognition in noise among Cl } \\
\text { users with three types of FM } \\
\text { system: traditional free-field, } \\
\text { desktop FM and personal FM } \\
\text { coupled by DAl }\end{array}$} & $\begin{array}{l}\text { Age of the participants: }>18 \\
\text { and }<18 \text { years (excluded } \\
\text { from this analysis); }\end{array}$ \\
\hline & & & Intrasubject evaluation - \\
\hline & & & repeated measures (with \\
\hline & & & and without FM system, \\
\hline & & & $\begin{array}{l}\text { more than one condition } \\
\text { with FM); }\end{array}$ \\
\hline & States & & Randomized listening \\
\hline & & & $\begin{array}{l}\text { Conditions; } \\
\text { Várias listas randomizadac. }\end{array}$ \\
\hline & & & More than one participant; \\
\hline & & & Speech perception \\
\hline & & & $\begin{array}{l}\text { evaluation in noise; } \\
\text { Fixed use of the } \mathrm{S} / \mathrm{R} \text { ratio of } \\
+5 \text { to }+20 \mathrm{~dB} ; \\
\text { Monaural use of } \mathrm{Cl}\end{array}$ \\
\hline
\end{tabular}

Nine cross-sectional studies were analyzed; the minimum age of the children was 4 years, and the maximum age was 18 years. Global results suggest that the three types of FM system significantly improve speech recognition in noise, both for children and adults, regarding the performance without
FM. When the three types were compared, 2A the traditional free field did not present benefits in comparison to $\mathrm{Cl}$ for speech recognition in noise. The desktop FM system and the personal FM system significantly improve the performance in noise, in comparison to $\mathrm{Cl}$ alone. The personal FM system provides more benefits than other types of FM systems
Cross-sectional study; Translation to Portuguese, linguistic adaptation and revision of grammatical and idiomatic equivalence, as well as cultural adaptation; The questionnaire was used with 12 professors and 1 speech language pathologist of 12 children aged from 7-13 years old, with hearing impairment, wearing hearing aid devices, and adapted for the FM system

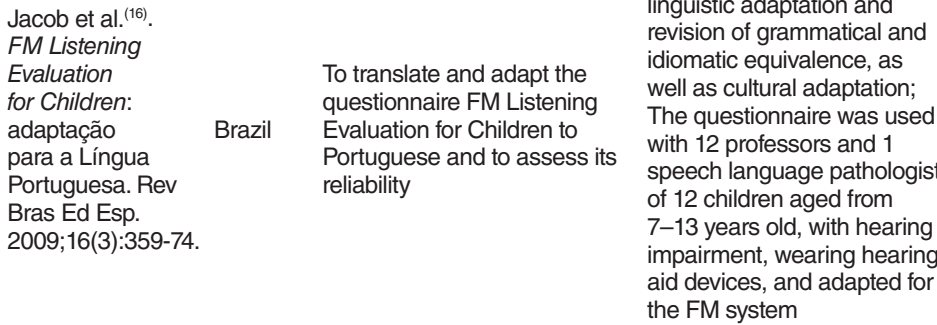

The translation and the adaptation of the questionnaire resulted in the new inventory: Avaliação do Sistema FM, presenting significant differences between the results of noise and auditory path and silence; Distance and auditory path and silence; Auditory path and noise, distance and silence; $F M$ was considered to

$2 \mathrm{~B}$ Silence and noise and auditory path; There was significant difference without and with the FM system; the latter always showed lower score;

In the intraresearcher comparison, it was possible to see significant difference between: total score with FM; auditory path without FM and noise with FM; there was no correlation with age be a reliable instrument to verify the follow-up

of the benefits from the FM system
The authors suggest the indication of the personal FM system coupled by DAl for $\mathrm{Cl}$ users because this model presents more benefits for speech perception in noise than the other two types of FM system

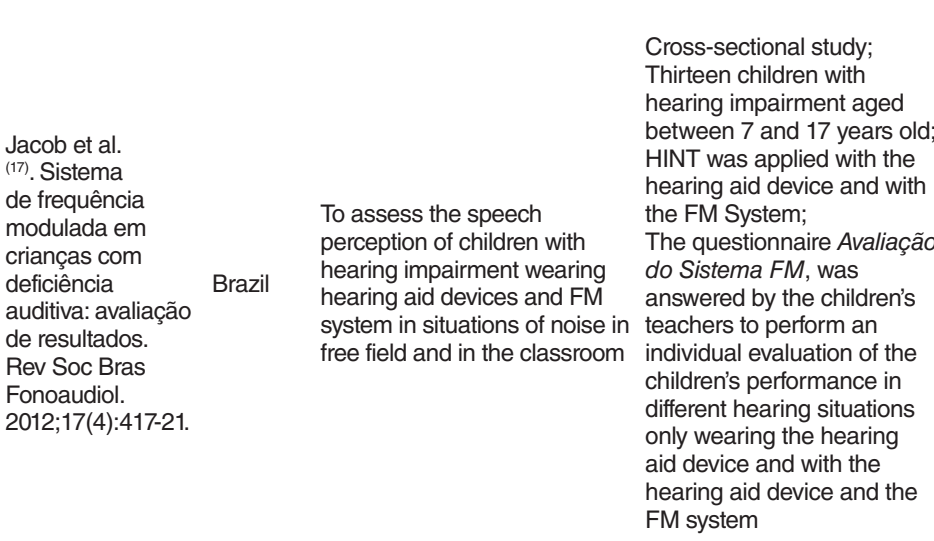

There were differences for all of the situations with and without a FM system in the HINT. The same was true for the results of the questionnaire; without the FM, the score was always lower than with the FM, regardless of the condition
The use of subjective methods, like the questionnaire, is essential to determine the efficacy of the indication of auxiliary devices for the person with hearing impairment. The effectiveness of the FM system can be observed by the "FM advantage", which is the minimal mean difference of $10 \mathrm{~dB}$ found in the speech perception evaluations with and without FM in the different noise situations

*Systematic review and meta-analysis

Caption: $\mathrm{Cl}=$ cochlear implant; $\mathrm{FM}=$ frequency modulation; $\mathrm{S} / \mathrm{N}=$ signal/noise; $\mathrm{DAI}=$ direct audio input; HINT = Hearing in Noise Test 


\section{SUMMARY OF FINDINGS}

On the basis of the analysis of the studies, it was possible to identify the reasons for the exclusion of articles; they were not fully analyzed for being repeated, or for presenting nonrelated themes, for not including the studied age group, for being in another language, among others. Out of the eight studies that were selected for the systematic review, three included only the population wearing CI: studies number 1, 2, and 6 . Study number 1 investigated speech perception in noise among children wearing $\mathrm{CI}$ together with the FM system, and study number 2 investigated speech perception, noise, and reverberation with a single FM system (free field) in two situations that were acoustically different in the school environment (ideal and poor acoustics). In study number 6 , through a systematic review and a meta-analysis, the authors verified if the three types of FM system provide better speech recognition in noise than the $\mathrm{CI}$ alone.

The analysis of the selected articles showed that study number 3 investigated speech perception, noise, and reverberation only among children wearing hearing aid devices, by using three types of technology (infrared, desktop FM, and personal FM).

Two other articles analyzed both users of hearing aid devices and CI. Study number 4 investigated speech perception among users of $\mathrm{CI}$ and/or hearing aid devices exposed in acoustically poor and ideal rooms, using three types of technology from the FM system (infrared, desktop FM, and personal FM). Study number 5 assessed the improvement in speech perception in noise provided by the three types of stimulation (bilateral, bimodal, and monaural) among users of hearing aid devices and/or CI together with the FM system. Studies number 7 and 8 only assessed children wearing hearing aid devices.

Regarding the evaluations performed in the studies in relation to speech perception in noise, it was possible to observe that six of them evaluated speech perception in noise (studies number 1, 3, 5, 6, 7, and 8) and two of them compared the speech perception in acoustically different environments: one that was acoustically poor and the other that was acoustically ideal (studies number 2 and 4 ).

From the articles that were fully analyzed, studies number $1,5,7$, and 8 only assessed the performance with the personal FM system, and the other studies analyzed the following three types of FM: free field, desktop FM, and personal FM, comparing their results.

The analysis of the papers regarding the type and level of evidence of each of them showed that only study number 6 was considered to be a systematic review and a meta-analysis with 2A level of evidence, and the rest of the studies were considered to be cohort, with $2 \mathrm{~B}$ level of evidence, according to the classification from the Oxford Centre for Evidence-Based Medicine $^{(9)}$ (Table 1).

\section{CONCLUSION}

It was possible to verify that the FM system improves speech perception and speech threshold in noise, and these results were found in all of the papers. Concerning the performance with relation to the type of FM system, the best results were obtained when children were wearing personal FM system, followed by desktop FM system and free field.

After a national and an international literature review, it was possible to conclude that studies indicate the need for analyses addressed to the impact of FM system on school performance of children who wear sensory devices together with the FM system because the findings in the eight papers analyzed in this study were addressed to the matter of speech perception in noise.

\section{ACKNOWLEDGMENTS}

I thank all of the researchers participating in the study "Proposta de Formação de Profissionais da Área da Educação sobre Deficiência de Audição e uso do Sistema de FM em Âmbito Nacional" (Multicenter Study: Cooperation Report N. 15850/FNDE).

*ALLB and RTSJ were in charge of the project, search and analysis of the studies included in the review, and the elaboration of the article; RTSJ, $A C P, M M, M A N M, M C B, S A B$, and ALMM were responsible for the general orientation of the stages of execution and elaboration of the manuscript.

\section{REFERENCES}

1. Brasil [Internet]. Portaria GM n 2.073, de 28 de setembro de 2004. Institui a Política Nacional de Atenção à Saúde Auditiva. Projeto de Lei do Senado $n^{\circ}$ 504, de 2003. [cited 2010 Jul 5]. Available from: http:// www.senado.gov.br/senadores/Senador/PauloPaim/pages/projetos/ Projetos/PLS/PLS\%20N\%\%20504\%20de\%202003\%20\%20teste\%20 da\%20orelinha.PDF http://dtr2001.saude.gov.br/sas/PORTARIAS/ Port2004/GM/GM-2073.htm

2. Delgado-Pinheiro EMC, Antonio FL, Libardi AL, Seno MP. Programa de acompanhamento fonoaudiológico de professores de alunos deficientes auditivos que utilizam a comunicação oral. Distúrb Comum. 2009;21(1):67-77.

3. Brasil [Internet]. Plano Nacional dos Direitos da Pessoa com Deficiência "Viver sem Limite". Pauta Inclusiva n 1. Dez./2011 [cited 2012 Nov 17]. Available from: http://www.pessoacomdeficiencia.gov.br/app/sites/ default/files/arquivos/.pdf

4. Brasil [Internet]. Política Nacional de Educação Especial. Livro 1/MEC/ SEESP. Brasília: Secretaria de Educação Especial; 1994.

5. Ross M. Room acoustics and speech perception. In: Ross M, editor. FM auditory training systems: characteristics, selection and use. Timoniun: York Press. 1992. p. 21-44.

6. Ross M. FM Systems: a little history and some personal reflections. In: Fabry D, Johnson CD, editors. Acess: Achieving Clear Communication Employng Sound Solutions. In: 1st International FM Conference; 2004; Great Britain. Proceedings. Great Britain: Cambrian Printers; 2004; 17-27.

7. Blasca WQ, Ferrari DV, Jacob RTS. Dispositivos eletrônicos aplicados à surdez: conceitos básicos. In: Genaro KF, Lamonica DC, Bevilacqua MC, organizadores. O processo de comunicação: contribuição para a formação de professores na inclusão de indivíduos com necessidade educacionais especiais. São José dos Campos: Pulso; 2006. p. 197-213.8. Brasil. Conselho Nacional de Secretários de Saúde. Portaria no 1.274, de 25 de junho de 2013. Brasília: Conselho Nacional de Secretários de Saúde; 2013.

9. Oxford Centre for Evidence-Based Medicine [Internet]. Levels of Evidence. 2009 [cited 2012 Aug 19]. Available from: http://www.cebm. net/ocebm-levels-of-evidence/ 
10. Davies MG, Yellon L, Purdy C. Speech-in-noise perception of children using cochlear implants and FM Systems. The Australian and New Zealand J Audiol. 2001;23(1):52-62.

11. Iglehart F. Speech perception by students with cochlear implants using sound-field systems in classrooms. Am J Audiol. 2004;13:62-72.

12. Anderson KL, Goldstein H. Speech perception benefits of FM and infrared devices to children with hearing aids in a typical classroom. Lang Speech Hear Serv Sch. 2004;35:169-84.

13. Anderson KL, Goldstein H, Colodzin L, Iglehart F. Benefit of S/N enhancing devices to speech perception of children listening in a typical classroom with hearing aids or a cochlear implant. J Educ Audiol. 2005;12:16-30.
14. Schafer EC, Thibodeau LM. Speech recognition in noise in children with cochlear implants while listening in bilateral, bimodal, and FM-System arrangements. Am J Audiol. 2006;15:114-26.

15. Schafer EC, Kleineck MP. Improvements in speech recognition using cochlear implants and three types of FM Systems: a meta-analytic approach. J Educ Audiol. 2009;15:4-14.

16. Jacob RT, Molina SV, Amorim RB, Bevilacqua MC, Lauris JR, Moret ALM. FM Listening Evaluation for Children: adaptação para a Língua Portuguesa. Rev Bras Ed Esp. 2009;16(3):359-74.

17. Jacob RTS, Bevilacqua MC, Molina SV, Queiroz M, Hoshii L A, Lauris JRP, et al. Sistema de frequência modulada em crianças com deficiência auditiva: avaliação de resultados. Rev Soc Bras Fonoaudiol. 2012;17(4):417-21. 